\title{
Restoration of 5-Bromouracil-sensitized Escherichia coli Strain B after Exposure to Ionizing or Ultraviolet Radiation
}

\author{
By N. E. GILLIES \\ Department of Biology as Applied to Medicine, \\ Middlesex Hospital Medical School, London, W.1
}

(Received 1 February 1966)

\begin{abstract}
SUMMARY
Escherichia coli strain B was sensitized to the action of $\gamma$-radiation or ultraviolet (u.v.) radiation by incorporating 5-bromouracil into the DNA of the bacteria. Most sensitization was observed after u.v. irradiation, less after anoxic $\gamma$-irradiation and least after aerobic $\gamma$-irradiation. Incubation of the bacteria for a few hours after irradiation on a nutrient medium which included chloramphenicol generally resulted in extensive restoration of colony-forming ability whether or not the bacteria contained 5-bromouracil. Only after the aerobic $\gamma$-irradiation of bacteria containing no bromoruacil was little restoration obtained, After aerobic or anaerobic $\gamma$-irradiation the 'rescue' of bacteria containing 5-bromouracil was relatively larger than that observed for bacteria containing no bromouracil. Maximum restoration was obtained after u.v. irradiation and this occurred to about the same extent, whether or not bromouracil had been incorporated into the bacteria. The results suggest that treatment with chloramphenicol decreases the expression of radiation-induced lesions which occur in the bacterial DNA; this may account for the mechanism of action of the inhibitor.
\end{abstract}

\section{INTRODUCTION}

It is well known that the amount of lethal radiation damage which is expressed in bacteria is partly dependent on the manner in which the organisms are treated after irradiation. Treatments which modify radiation response do so, in many instances, by affecting the rate of metabolic processes in the irradiated organisms. With Escherichia coli strain B and some of the strains derived from it, the rate of protein synthesis is critical in determining whether or not a considerable proportion of the irradiated bacteria survive as colony formers. Thus, marked restoration of the colony-forming ability of $\boldsymbol{E}$. coli B after exposure to ultraviolet (u.v.) or ionizing radiation can be effected by incubating the bacteria for the initial period after irradiation with chloramphenicol (Gillies \& Alper, 1959), or by temporarily depriving irradiated auxotrophic strains of $E$. coli B of an essential amino acid (Gillies, 1961; Forage \& Gillies, 1964). It is believed that this effect is due to the specific inhibition of protein synthesis. On the other hand, Alper (1963) showed that the survival of the radiation-resistant strain $E$. coli $\mathrm{B} / \mathbf{r}$ is decreased when it is treated with chloramphenicol after irradiation. The expression of some types of mutational change in bacteria is also dependent on synthesis of protein after irradiation (Witkin, 1956; Doudney \& Haas, 1958; Witkin \& Theil, 1960) and in general, conditions 
which slow or completely prevent protein synthesis lead to a decrease in the yield of mutants.

In general, conditions which prevent growth or decrease the rate of growth of Escherichia coli в cause restoration of colony-forming ability of a fraction of the irradiated population (Alper \& Gillies, 1958, 1060) and in broad terms an explanation of the action of chloramphenicol in promoting this restoration can be offered. However, nothing is known about the mechanism by which damage, which would otherwise have developed irreversibly, is removed during a period of arrest of protein synthesis immediately after irradiation. The solution of this problem is hampered by lack of knowledge of the nature of the critical lesions caused by radiations in cells, but there is at least one type of damage induced by u.v. and $\gamma$ radiation which appears to be identifiable with a site or sites in the DNA of cells. This is the additional lesion, first detected by Greer (1960) in u.v. irradiated E. coli $15 \mathrm{~T}$, which shows up when a fraction of the thymine of the cellular DNA is replaced by the halogenated derivative of thymine, 5-bromouracil (5-BU). It therefore appeared worth while to determine whether or not bacteria which had been sensitized to either u.v. or ionizing radiation by the presence of 5-BU in their DNA could be restored by incubation with chloramphenicol after irradiation. By this approach information seemed likely to be gained about the mode of action of chloramphenicol in restoring the colony-forming ability of irradiated bacteria, and possibly also on the mechanism of the sensitization brought about by $5-\mathrm{BU}$.

\section{METHODS}

Organism. The strain B of Escherichia coli was the same as that used in previous work (Alper \& Gillies, 1958, 1960; Gillies \& Alper, 1959). It was maintained on slopes of Oxoid nutrient agar stored at $4^{\circ}$.

Growth and preparation of bacteria for irradiation. Bacteria required for experiment were first grown in a minimal medium by subculturing into an inorganic salts glucose medium (Lederberg, 1950) followed by overnight incubation at $37^{\circ}$ for $15 \mathrm{hr}$. Incorporation of 5-bromouracil (5-BU) into the bacteria was effected by inoculating about $4 \times 10^{7}$ organisms from the overnight culture into $20 \mathrm{ml}$. of a defined medium containing 5 -BU in a $100 \mathrm{ml}$. bottle which was rotated on an angled turntable at $37^{\circ}$ for $6 \mathrm{hr}$. In this way adequate aeration of the culture was obtained; this was essential for rapid growth and for measurable radiation-sensitization of the bacteria to occur. The concentration of the suspension at the end of the incubation period was about $5 \times 10^{7}$ bacteria/ml. The composition of the defined growth medium is shown in Table 1; it is based upon the medium used by Kaplan, Smith \& Tomlin (1962). It contained 5-BU (75 $\mu \mathrm{g} . / \mathrm{ml}$.) and also sulphanilamide $(0 \cdot 2 \%)$ to inhibit the action of folic acid which is required for de novo synthesis of thymidylic acid. The control population of bacteria which did not contain 5-BU was grown at the same time in the same medium except that thymine $(75 \mu \mathrm{g} . / \mathrm{ml}$.) replaced the 5-BU. The bacteria were harvested by centrifugation, washed twice in $\mathbf{m} / \mathbf{1 5}$ phosphate buffer $(\mathrm{pH} 7$ ) and finally resuspended for irradiation in buffer at a concentration of about $6 \times 10^{6} \mathrm{bacteria} / \mathrm{ml}$. 


\section{Irradiation of bacteria}

With $\gamma$-rays. Bacteria were exposed to radiation from a ${ }^{60} \mathrm{Co}$ source (VickersArmstrong, Mark IV Hotspot Irradiation Unit) in the vessel described previously (Forage \& Gillies, 1964). Either oxygen or oxygen-free nitrogen ('white spot') was bubbled through the suspension as required. The dose rate delivered in the vessel, as measured by ferrous sulphate dosimetry (Miller \& Wilkinson, 1952), was $2 \cdot 2$ $\mathrm{krad} . / \mathrm{min}$. Irradiations were performed at room temperature.

Table 1. Composition of the defined sulphanilamide medium in which Escherichia coli $в$ was grown before irradiation Sulphanilamide was used to inhibit the endogenous synthesis of thymidylic acid.
5-bromouracil (5-BU) or thymine was added as required. Adjusted to $\mathrm{pH} \mathbf{7 \cdot 3}$.

\begin{tabular}{|c|c|c|c|}
\hline Constituent & $\%(w / v)$ & Constituent & $\%(w / v)$ \\
\hline $\mathrm{K}_{2} \mathrm{HPO}_{4}$ & $0 \cdot 7$ & Xanthine & $0 \cdot 003$ \\
\hline $\mathrm{KH}_{2} \mathrm{PO}_{4}$ & 0.2 & Pyridoxine & $0 \cdot 0001$ \\
\hline $\mathrm{Na}$ citrate $.2 \mathrm{H}_{2} \mathrm{O}$ & 0.004 & Thiamine & 0.0001 \\
\hline $\mathrm{MgSO}_{4} \cdot 7 \mathrm{H}_{2} \mathrm{O}$ & $0 \cdot 001$ & Glucose & $0 \cdot 3$ \\
\hline$\left(\mathrm{NH}_{4}\right)_{2} \mathrm{SO}_{4}$ & $0 \cdot 01$ & Sulphanilamide & $\mathbf{0 \cdot 2}$ \\
\hline DL-methionine & 0.003 & Thymine or 5-bromouracil & 0.0075 \\
\hline DL-serine & 0.003 & & \\
\hline DL-valine & 0.003 & & \\
\hline L-histidine & 0.003 & & \\
\hline
\end{tabular}

With $X$-rays. In a few experiments X-rays $(190 \mathrm{kV}$., $3 \mathrm{~mA}$.) from a General Electric X-ray Corporation KX-10 Unit were used. The bacteria were irradiated under controlled gas conditions in the type of vessel described by Alper (1955). The dose rate of unfiltered radiation delivered to the suspension in the vessel was $0 \cdot 4 \mathrm{krad} . / \mathrm{min}$.

With ultraviolet radiation. Ten ml. of the bacterial suspension was placed in an open glass dish (diam. $8.5 \mathrm{~cm}$.) and exposed, at room temperature, to u.v. radiation from a $15 \mathrm{~W}$. Hanovia water-jacketed bactericidal tube which delivered more than $90 \%$ of its radiation at $2537 \AA$. The dish was gently shaken during exposure. The dose rate was $155 \mathrm{ergs} / \mathrm{mm} .{ }^{2} / \mathrm{min}$., as measured with a u.v. sensitive photometer originally calibrated by $\mathrm{Dr}$ R. Latarjet.

\section{Treatment of bacteria after irradiation}

To determine the effect of temporarily treating bacteria containing thymine (thymine bacteria) and bacteria containing 5-BU (5-BU bacteria) with chloramphenicol, the technique of growing irradiated bacteria on cellophan carriers lying on the incubation medium was used (Alper \& Gillies, 1958). This allowed bacteria to be transferred quickly from one medium to another. Suitable dilutions of the irradiated bacteria were dispensed on cellophan carriers lying on the surface of a series of plates of Oxoid nutrient agar containing chloramphenicol $(5 \mu \mathrm{g} . / \mathrm{ml}$.), pre-warmed to $37^{\circ}$. The inoculated plates were returned to the incubator, and at intervals a plate was removed and the bacteria transferred on their carriers to fresh pre-warmed plates of Oxoid nutrient agar containing no inhibitor. The macrocolonies which subsequently developed after overnight incubation at $37^{\circ}$ were 
counted. Samples of un-irradiated bacteria were treated in the same fashion. The number of macrocolonies which grew after a given treatment was determined as the average count obtained from bacteria seeded on six replicate pieces of cellophan. Where errors are indicated these represent the $95 \%$ confidence limits of the colony count.

\section{RESULTS}

Under the conditions used the rate of growth of Escherichia coli $\mathbf{B}$, as determined by colony count, was the same for the first $6 \mathrm{hr}$ of incubation whether thymine or 5-BU was included in the sulphanilamide medium (Fig. 1). However, after that

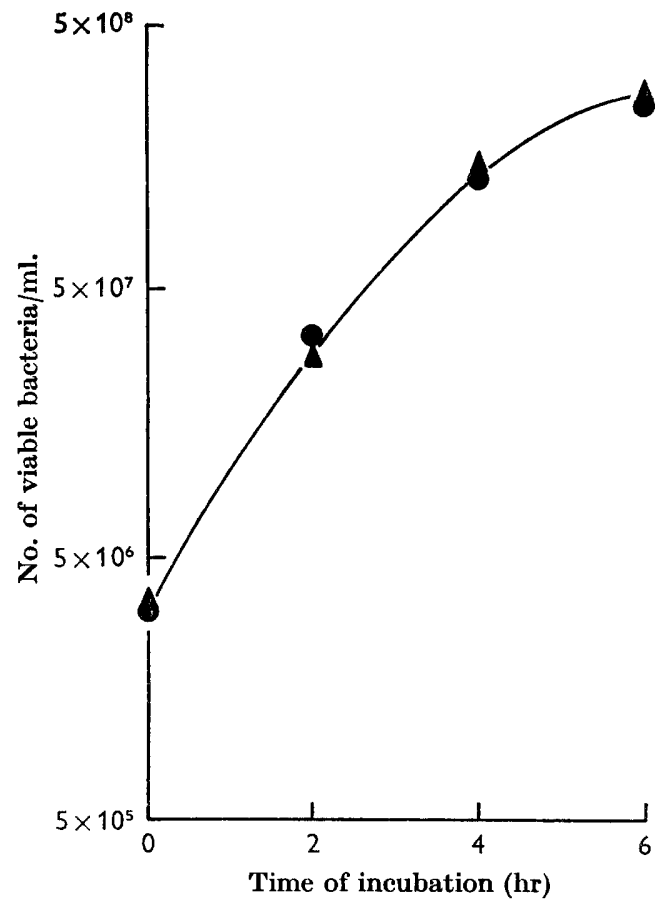

Fig. 1

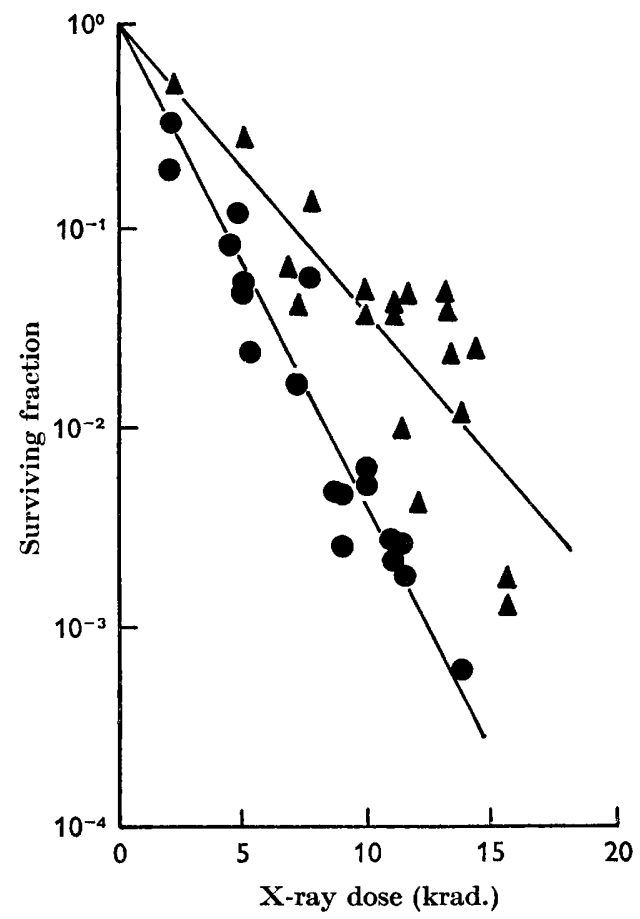

Fig. 2

Fig. 1. Growth of Escherichia coli strain $\mathbf{B}$ in sulphanilamide medium containing: 5-bromouracil (5-BU; $75 \mu \mathrm{g} . / \mathrm{ml}$.); $\Delta$, thymine $(75 \mu \mathrm{g} . / \mathrm{ml}$.)

Fig. 2. Survival of Escherichia coli strain B after exposure to $\gamma$-radiation under aerobic conditions. Bacteria were grown before irradiation in : e, sulphanilamide medium +5-BU; $\Delta$, sulphanilamide medium + thymine.

time the rate of growth of 5-BU bacteria decreased below that of thymine bacteria. This was probably due to the lethal action of high concentrations of 5-BU and possibly also to the inhibition of division as the bacteria accumulated more 5-BU. Since significant radiation-sensitization of the 5-BU bacteria occurred by $6 \mathrm{hr}$, the bacteria were harvested at that time, and irradiated as a suspension in buffer $(\mathrm{pH} 7 \cdot 0)$.

In Figs. 2 and 3 data are presented on the $\gamma$-radiation sensitivities of 5 -BU and of thymine bacteria irradiated in the presence and absence of oxygen, respectively. 
Each point, derived from a separate experiment, represents the surviving fraction of bacteria, on Oxoid nutrient agar containing no chloramphenicol, after exposure to a given dose of $\gamma$ radiation. There was considerable scatter in the experimental points, particularly for thymine bacteria irradiated under oxygen. Difficulty was experienced in maintaining uniform radiation sensitivity over the 2-year period during which the experiments were made. These variations may reflect minor differences in the composition of the batches of sulphanilamide medium used as well as other uncontrolled factors which affect the radiation-sensitivity of bacteria grown in defined media. However the response of the bacteria to the post-irradiation treatments was reproducible, despite these variations in radiation-sensitivity. The lines which have been drawn through the points were fitted by least-square analysis according to the method of Moore \& Edwards (1965). The calculated slopes of the lines are shown in Table 2. Despite the considerable scatter in the experimental points plotted in Figs. 2 and 3, the standard deviations of the calculated slopes are small, being less than $10 \%$ in each case, because a large number of observations were used to define the slopes of the lines, The extent of sensitization to $\gamma$ radiation effected by 5-BU was measured by calculating the ratio of the slopes of the survival curves of the thymine and 5-BU bacteria. The oxygen enhancement ratios for 5-BU and thymine bacteria were calculated as the ratios of the slopes of the survival curves obtained after irradiation of the bacteria in the absence and presence of oxygen respectively. These ratios are also included in Table 2.

Table 2. Calculated slopes of survival curves for Escherichia coli $B$ exposed to $\gamma$-radiation in the presence or absence of oxygen

\footnotetext{
The bacteria were grown in sulphanilamide medium +thymine (thymine bacteria) or in sulphanilamide medium +5-BU (5-BU bacteria). The oxygen enhancement ratio is the ratio of the slope of the survival curve obtained after aerobic radiation to that of the survival curve obtained after anaerobic radiation. The errors shown are the standard deviations of the calculated slopes.

\begin{tabular}{|c|c|c|c|}
\hline & Aerobic & Anaerobic & $\begin{array}{c}\text { Oxygen } \\
\text { enhancement } \\
\text { ratio }\end{array}$ \\
\hline $\begin{array}{l}\text { 5-BU bacteria } \\
\text { Thymine bacteria }\end{array}$ & $\begin{array}{l}0 \cdot 239 \pm 0 \cdot 0063 \\
0 \cdot 145 \pm 0 \cdot 0071\end{array}$ & $\begin{array}{l}0.0834 \pm 0.0068 \\
0.0402 \pm 0.00095\end{array}$ & $\begin{array}{l}2 \cdot 86 \pm 0 \cdot 248 \\
3 \cdot 60 \pm 0 \cdot 195\end{array}$ \\
\hline
\end{tabular}

Extent of sensitization of Escherichia coli B by 5-BU to $\gamma$-radiation, Sensitization by 5-BU was measured as the ratio of the slope of the survival curve for 5-BU bacteria to that of the survival curve for thymine bacteria.

Condition of $\gamma$-radiation: aerobic, $1 \cdot 65 \pm 0 \cdot 091$; anaerobic, $2 \cdot 07 \pm 0 \cdot 178$.
}

The sensitivity of 5-BU and thymine bacteria to u.v. radiation is illustrated in Fig. 4, the points being derived from data obtained from a series of separate experiments. The inconsistency in the sensitivity of the thymine bacteria precludes an accurate measure of the sensitization effected by $5-\mathrm{BU}$, but it appears to be by a factor of at least $2 \cdot 3$.

\section{The response of 5-BU bacteria and thymine bacteria to treatment with chloramphenicol}

After $\gamma$-irradiation under aerobic conditions. The effect of incubating 5-BU or thymine bacteria of Escherichia coli $\mathbf{B}$ on nutrient medium containing 
chloramphenicol for various intervals after aerobic $\gamma$-irradiation is shown in Fig. 5. At the times indicated on the abscissa the bacteria on their cellophan carriers were transferred to nutrient medium containing no chloramphenicol. In this particular experiment 5-BU bacteria and thymine bacteria were decreased to approximately the same survival values, before treatment with chloramphenicol, by exposing them to $7 \cdot 1 \mathrm{krad}$, and $\mathbf{1 4 \cdot 2} \mathrm{krad}$. of $\gamma$-radiation respectively, The surviving fraction of thymine bacteria was little affected by incubation with chloramphenicol, whereas treatment of the 5-BU bacteria led to a fivefold increase in the numbers of bacteria

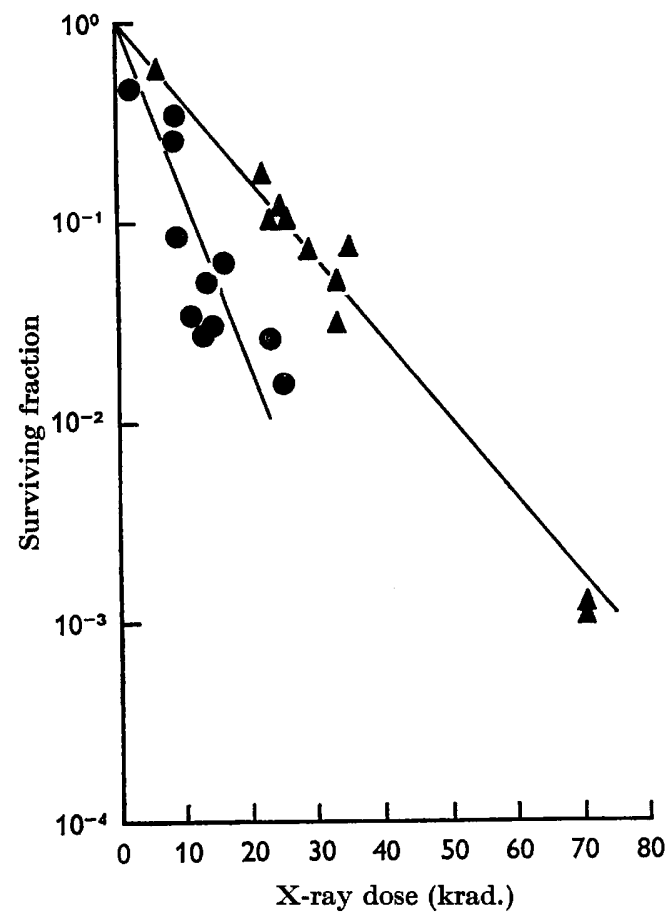

Fig. 3

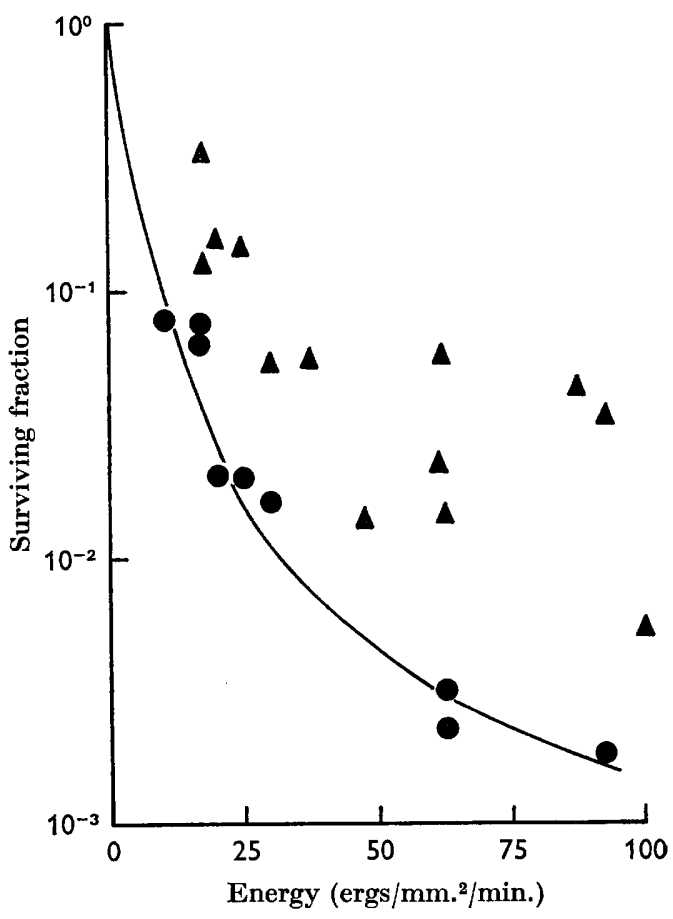

Fig. 4

Fig. 3. Survival of Escherichia coli strain в after exposure to $\gamma$-radiation under anaerobic conditions. Bacteria were grown before irradiation in: $\bullet$, sulphanilamide medium $+5-\mathbf{B U}$; $\Delta$, sulphanilamide medium + thymine.

Fig. 4. Survival of Escherichia coli strain B after exposure to ultraviolet radiation. Bacteria were grown before irradiation in: $\bullet$, sulphanilamide medium $+5-\mathrm{BU} ; \boldsymbol{\Delta}$, sulphanilamide medium + thymine.

able to originate colonies, although even then the survival was not as great as that of the untreated thymine bacteria; this is illustrated in Fig. 6. In this case, the two bacterial populations were each exposed to equal doses of $9 \mathrm{krad}$. of $\gamma$-radiation under oxygen. The extent of sensitization by 5 -BU is evidenced by the much lower survival of the 5-BU bacteria when plated immediately after irradiation on nutrient medium containing no chloramphenicol. As before, incubation with chloramphenicol afforded a large increase in the survival of the 5-BU bacteria and little or no increase in the survival of the thymine bacteria, but the surviving fraction of 5-BU bacteria 
after this 'rescuing' treatment still fell short of that of the thymine bacteria. Thus, the restoration brought about by chloramphenicol was relatively more effective in 5-BU bacteria than in thymine bacteria after aerobic $\gamma$-irradiation. However, in some experiments significant rescue of the thymine bacteria did occur, amounting to a two-/threefold increase in the surviving fraction. In these instances the rescue of 5-BU bacteria treated in parallel was even more extensive.

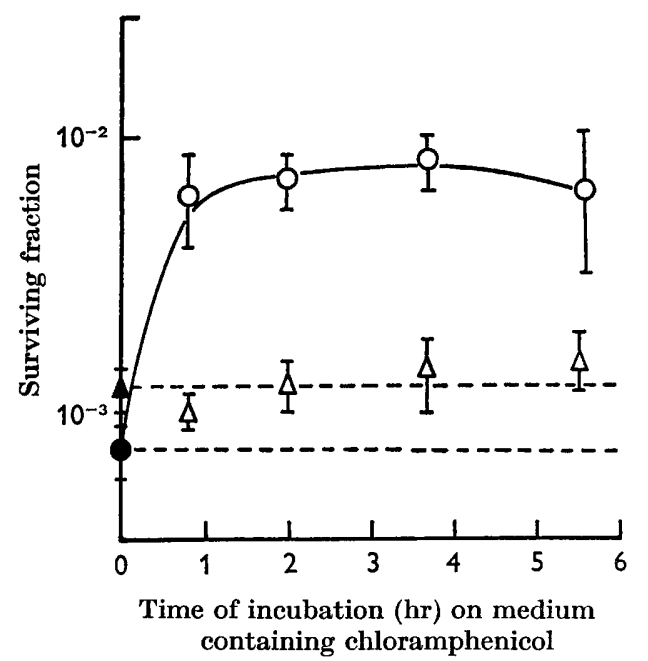

Fig. 5

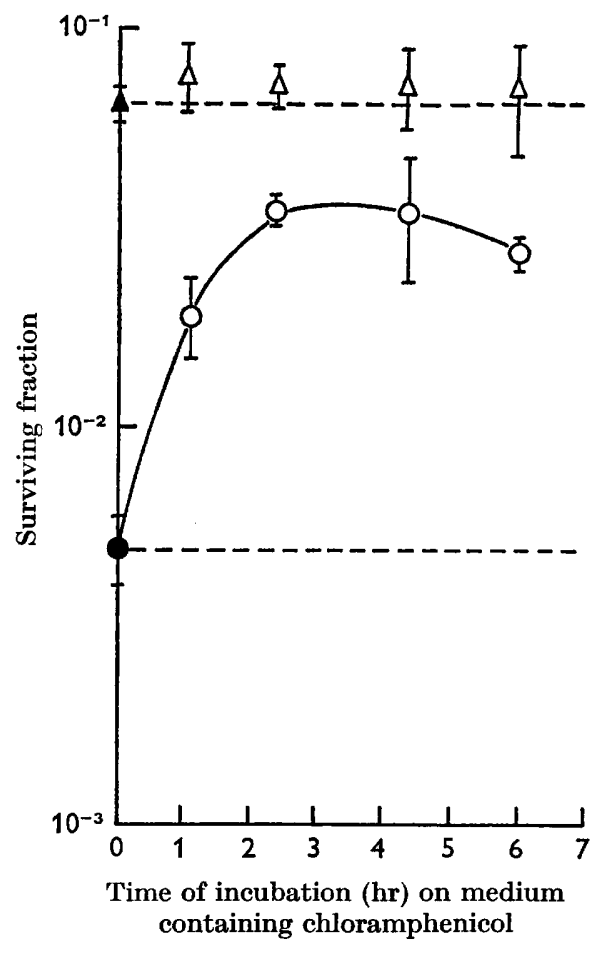

Fig. 6

Fig. 5. Survival of Escherichia coli strain B after exposure to $\gamma$-radiation under aerobic conditions, - - -, grown in sulphanilamide medium +5-BU before irradiation; incubated throughout on Oxoid nutrient agar after exposure to $7 \cdot 1 \mathrm{krad}$. $\gamma$-radiation. $\bigcirc$, Grown in sulphanilamide medium + 5-BU before irradiation; incubated on Oxoid nutrient agar + chloramphenicol ( $5 \mu \mathrm{g}$. $/ \mathrm{ml}$.) after exposure to $7 \cdot 1 \mathrm{krad}$. of $\gamma$-radiation, for the intervals indicated on the abscissa and then transferred to Oxoid nutrient agar. $\mathbf{A}-\ldots$, Grown in sulphanilamide medium + thymine before irradiation; incubated throughout on Oxoid nutrient agar after exposure to $14.2 \mathrm{krad}$. of $\gamma$-radiation. $\triangle$, Grown in sulphanilamide medium + thymine before irradiation; incubated on Oxoid nutrient agar + chloramphenicol ( $5 \mu \mathrm{g} . / \mathrm{ml}$.), after exposure to $14.2 \mathrm{krad}$. of $\gamma$-radiation, for the intervals indicated on the abscissa, and then transferred to Oxoid nutrient agar.

Fig. 6. Survival of Escherichia coli strain в after exposure to $9 \mathrm{krad}$. $\gamma$-radiation under aerobic conditions. - - - , Grown in sulphanilamide medium +5-BU before irradiation; incubated throughout on Oxoid nutrient agar, after irradiation. $\bigcirc$, Grown in sulphanilamide medium + 5-BU before irradiation; incubated on Oxoid nutrient agar + chloramphenicol after irradiation for the intervals indicated and then transferred to Oxoid nutrient agar. $\Delta--$, Grown in sulphanilamide medium + thymine before irradiation; incubated throughout on Oxoid nutrient agar after irradiation. $\triangle$, Grown in sulphanilamide medium + thymine before irradiation; incubated on Oxoid nutrient agar + chloramphenicol after irradiation for the intervals indicated and then transferred to Oxoid nutrient agar. 
To provide a measure of the effect of treatment with chloramphenicol, a value, which we have called the Rescue Index, was calculated. This is the maximum number of bacteria which were rescued, expressed as \% of the bacteria which would not form colonies if not incubated with chloramphenicol. For example, when a certain dose of $\gamma$-radiation initially decreased the surviving fraction of bacteria to $0 \cdot 01$, and incubation with chloramphenicol increased the surviving fraction to a maximum value of 0.06 , then the Rescue Index is $[(0.06-0.01) /(1 \cdot 00-0.01)]$ $\times 100=5 \cdot 05$. Thus, the more extensive the restoration, the larger is the value of

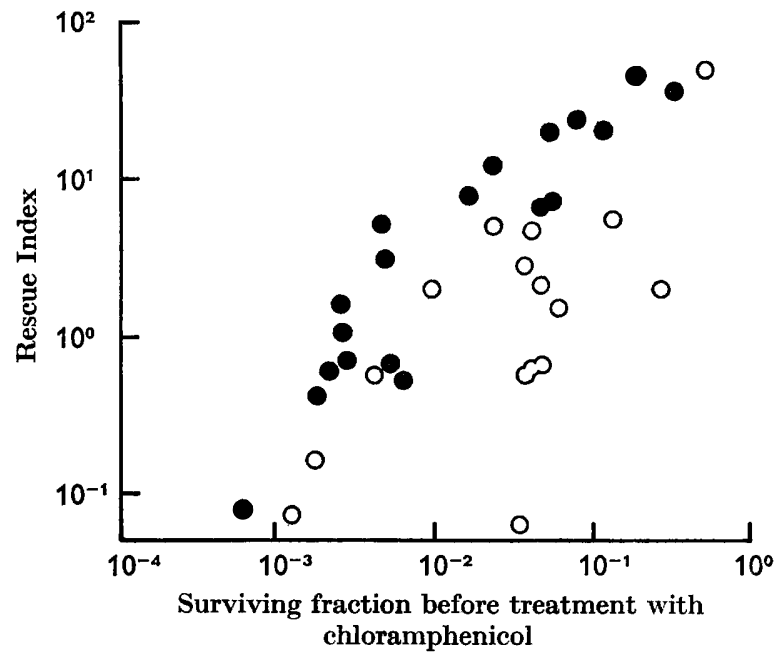

Fig. 7

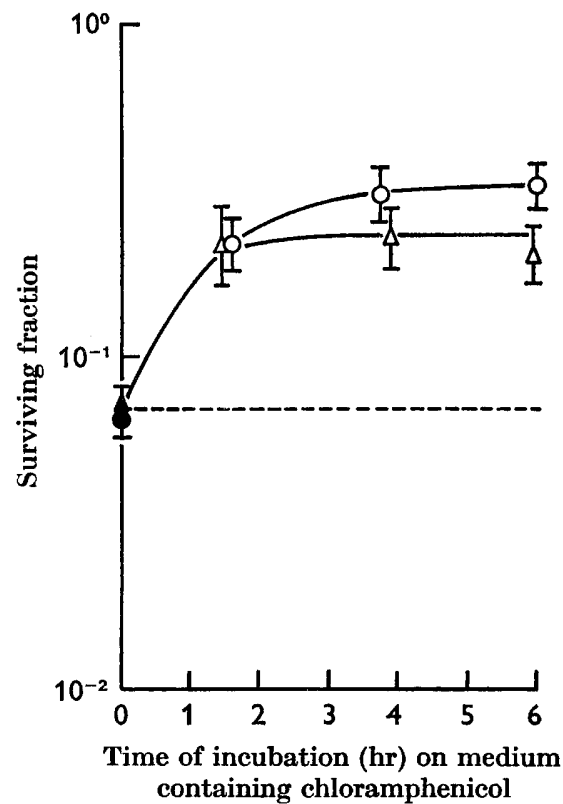

Fig. 8

Fig. 7. Rescue Indices for Escherichia coli strain B plotted against the surviving fractions obtained when the bacteria had not been incubated with chloramphenicol after aerobic $\gamma$-irradiation. The definition and the method of calculating the Rescue Index are given in the text. 9 , Containing 5-BU; $O$, containing thymine.

Fig. 8. Survival of Escherichia coli strain B after exposure to $\gamma$-radiation under anaerobic conditions. - - - Grown in sulphanilamide medium +5-BU before irradiation; incubated throughout on Oxoid nutrient agar after exposure to $16 \cdot 1 \mathrm{krad}$. of $\gamma$-radiation. $O$, Grown in sulphanilamide medium + 5-BU before irradiation, incubated on Oxoid nutrient agar + chloramphenicol, after exposure to $16 \cdot 1 \mathrm{krad}$. of $\gamma$-radiation, for the intervals indicated and then transferred to Oxoid nutrient agar. $\Delta---$, Grown in sulphanilamide medium + thymine before irradiation; incubated throughout on Oxoid nutrient agar after exposure to $34.8 \mathrm{krad}$. of $\gamma$-radiation. $\triangle$, Grown in sulphanilamide medium + thymine before irradiation; incubated on Oxoid nutrient agar + chloramphenicol, after exposure to $34.8 \mathrm{krad}$. of $\gamma$-radiation, for the intervals indicated, and then transferred to Oxoid nutrient agar.

the Rescue Index. The data obtained from a series of experiments have been summarized in Fig. 7 by plotting the calculated Rescue Indices against the survival observed when the bacteria were not treated with chloramphenicol. Both parameters have been plotted on a logarithmic scale to give the results conveniently in one 
figure. Because of variations in the radiation-sensitivity of the bacteria observed in the experiments it was decided to plot the Rescue Indices against survival without restoration treatment, rather than against the dose of radiation used, as a means of obtaining a more valid comparison of the two populations of bacteria.

Since the surviving fraction of colony formers decreased with increasing exposure to radiation, the $\%$ of killed $5-\mathrm{BU}$ and thymine bacteria which can be restored also decreased; this is indicated by the decrease in Rescue Index as the surviving fraction of the unrescued bacteria decreased. Although there is a large scatter in the points,

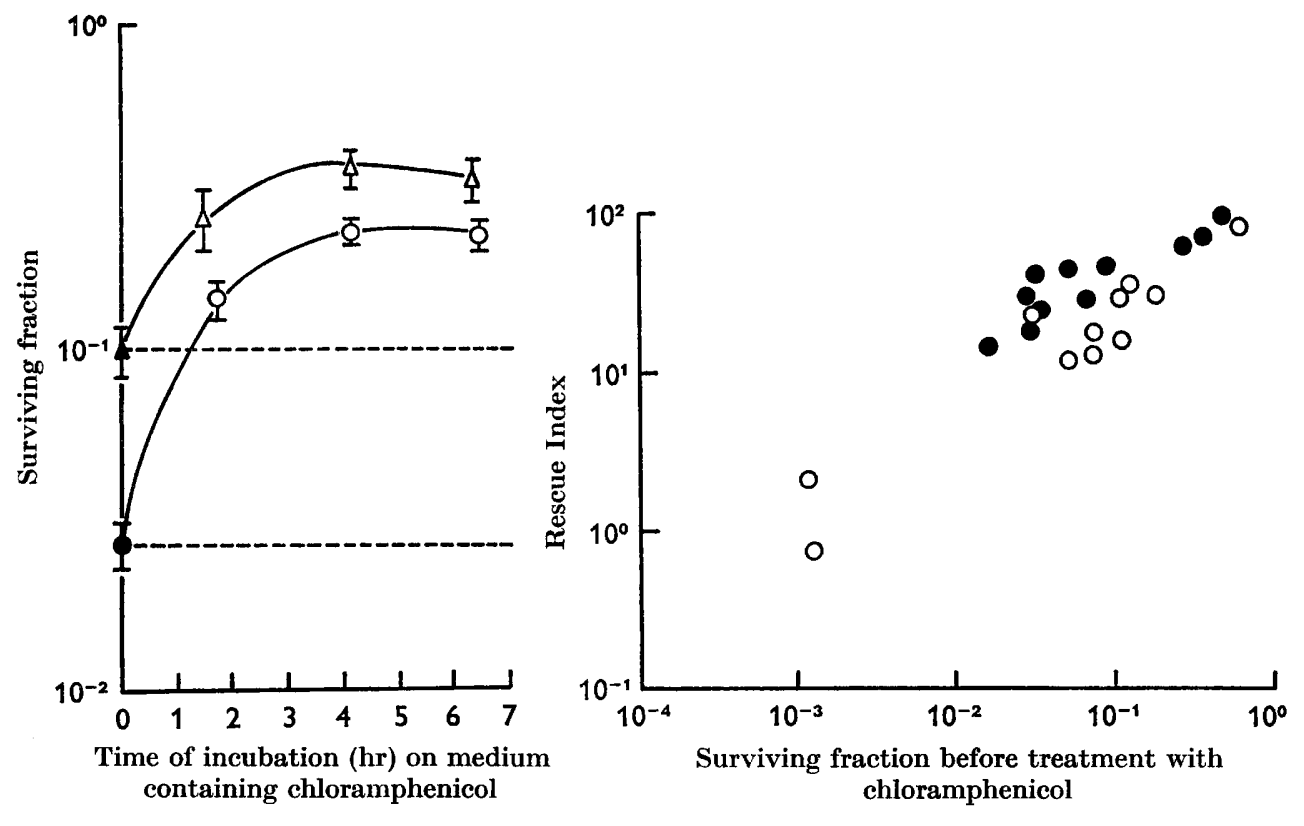

Fig. 9

Fig. 10

Fig. 9. Survival of Escherichia coli strain B after exposure to $23 \cdot 2 \mathrm{krad}$. of $\gamma$-radiation under anaerobic conditions. - - - grown in sulphanilamide medium +5-BU before irradiation; incubated throughout on Oxoid nutrient agar after irradiation. $O$, Grown in sulphanilamide medium + 5-BU before irradiation; incubated on Oxoid nutrient agar + chloramphenicol after irradiation for the intervals indicated and then transferred to Oxoid nutrient agar. $\mathbf{\Delta}---$, Grown in sulphanilamide medium + thymine before irradiation; incubated throughout on Oxoid nutrient agar after irradiation. $\triangle$, Grown in sulphanilamide medium + thymine before irradiation; incubated on Oxoid nutrient agar + chloramphenicol for the intervals indicated and then transferred to Oxoid nutrient agar.

Fig. 10. Rescue Indices for Escherichia coli strain B plotted against the surviving fractions obtained when the bacteria had not been incubated with chloramphenicol after anaerobic $\gamma$-irradiation. Containing 5-BU; $O$, containing thymine.

particularly in those relating to thymine bacteria, the majority of the Rescue Indices for the 5-BU bacteria are larger than those for the thymine cells, indicating relatively greater restoration of the 5-BU bacteria. On two occasions treatment of irradiated thymine bacteria with chloramphenicol caused a decrease in survival and therefore no Rescue Index could be calculated in these cases.

After $\gamma$-irradiation under anaerobic conditions. The results from a typical experiment are illustrated in Fig. 8, in which is plotted the survival of thymine and 5-BU 
bacteria against the time of incubation on nutrient medium containing chloramphenicol. The thymine bacteria were exposed to $34 \cdot 8 \mathrm{krad}$. and the $5-\mathrm{BU}$ bacteria to $16 \cdot 1 \mathrm{krad}$. $\gamma$-radiation under anoxia to decrease them to the same degree of survival. Considerable restoration of both thymine and 5-BU bacteria occurred, but the extent of rescue of the 5-BU bacteria was just significantly greater. Figure 9 shows that for bacteria exposed to the same dose of $\gamma$-radiation under anoxia, the maximum degree of survival of thymine bacteria after treatment with chloramphenicol was higher than that of the 5-BU bacteria, even when the relative extent of restoration of the 5-BU bacteria was greater.

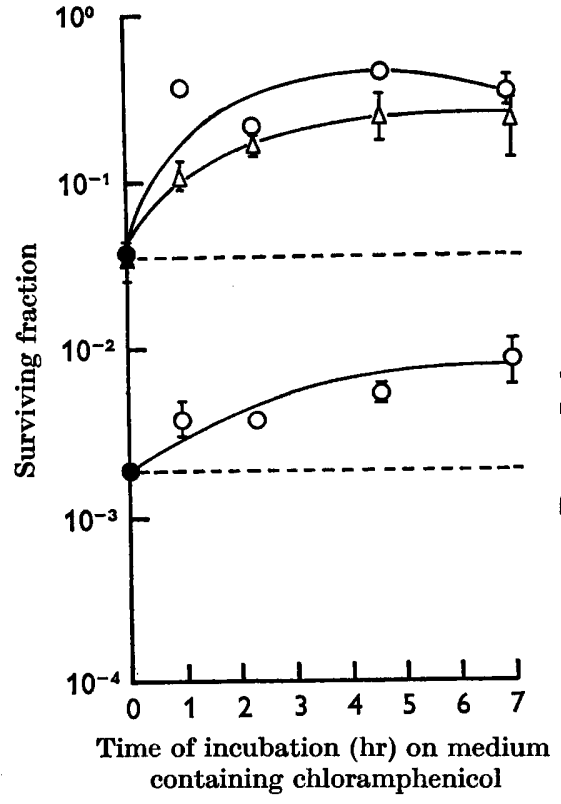

Fig. 11

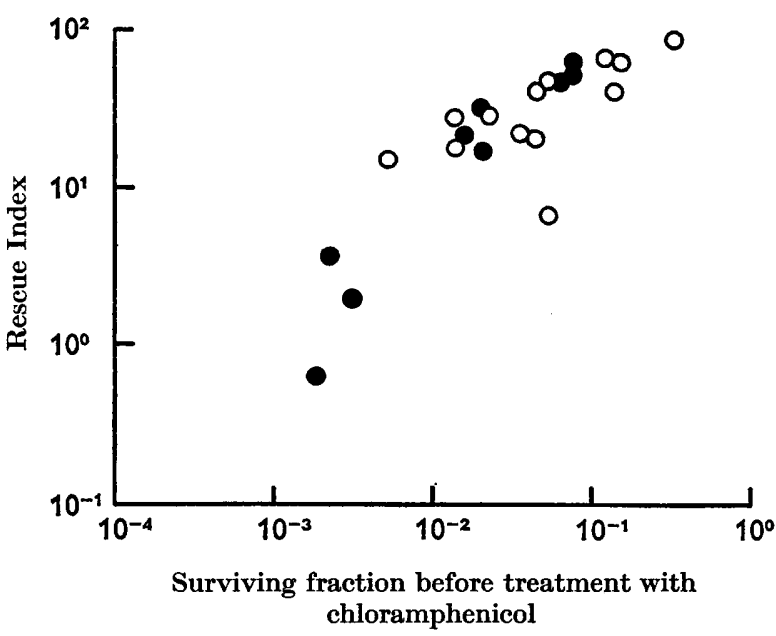

Fig. 12

Fig. 11. Survival of Escherichia coli strain B after exposure to u.v. radiation. Grown in sulphanilamide medium +5-BU before irradiation; incubated throughout on Oxoid nutrient agar after exposure to $18 \mathrm{ergs} / \mathrm{mm}^{2}$. (top curve) or to $95 \mathrm{ergs} / \mathrm{mm}^{2}$. (bottom curve) of u.v. radiation. $O$, Grown in sulphanilamide medium +5 -BU before u.v. irradiation; incubated on Oxoid nutrient agar + chloramphenicol after exposure to $18 \mathrm{ergs} / \mathrm{mm}^{2}$ (top curve) or to $95 \mathrm{ergs} / \mathrm{mm} .^{2}$ (bottom curve) of u.v. radiation. $\Delta---$, Grown in sulphanilamide medium + thymine before irradiation; incubated throughout on Oxoid nutrient agar after exposure to $95 \mathrm{ergs} / \mathrm{mm} .^{2}$ of u.v. radiation. $\triangle$, Grown in sulphanilamide medium + thymine before irradiation; incubated on Oxoid nutrient agar + chloramphenicol, after exposure to $95 \mathrm{ergs} / \mathrm{mm} .^{2}$ of u.v. radiation, for the intervals indicated, and then transferred to Oxoid nutrient agar.

Fig. 12. Rescue Indices for Escherichia coli strain B plotted against the surviving fractions obtained when the bacteria had not been incubated with chloramphenicol after u.v. irradiation. Containing 5-BU; $\bigcirc$, containing thymine.

After u.v. irradiation. The data presented in Fig. 11, which are taken from one experiment, indicate that extensive rescue of thymine bacteria and of 5-BU bacteria occurred after treatment with chloramphenicol on a nutrient medium. The two lower curves in Fig. 11 show that when thymine and 5-BU bacteria were exposed to 
the same dose of u.v. radiation (95 ergs. $/ \mathrm{mm}^{2}$ ), the surviving fractions were $3.66 \times$ $10^{-2}$ and $1.84 \times 10^{-3}$, respectively, when the cells were not treated with chloramphenicol. After incubation with chloramphenicol for $7 \mathrm{hr}$ the survival of the thymine bacteria increased to $2 \cdot 48 \times 10^{-1}$ and that of the 5 -BU bacteria to $8.13 \times 10^{-3}$. Therefore, the survival of thymine bacteria increased to a greater extent. However, when comparison is made between the effect of chloramphenicol on the thymine bacteria and the 5-BU bacteria decreased to the same survival with $18 \mathrm{ergs} . / \mathrm{mm}^{2}{ }^{2}$ of u.v. radiation, as shown in the upper curves of Fig. 11, the rescue of the 5-BU bacteria was significantly greater. When the Rescue Indices calculated from the data of several different experiments are plotted against survival of unrescued bacteria (Fig. 12) it appears that the restoration by chloramphenicol occurred to about the same extent in both thymine and 5-BU bacteria.

\section{DISCUSSION}

The extent of sensitization to $\gamma$-radiation due to the incorporation of 5-BU into Escherichia coli $\mathrm{B}$ was greater when the irradiation was performed under anoxic than under aerobic conditions. Despite the variations encountered in the sensitivity of the bacteria over a long time-interval this is clearly seen in the data presented in Table 2. These confirm the observation made by Alper \& Moore (1964), who worked with the same strain of $\boldsymbol{E}$. coli B. An examination of the data presented by Kaplan, Zavarine \& Earle (1962) suggest likewise that greater sensitization to $\mathrm{X}$ radiation was effected by $5-\mathrm{BU}$ in a thymine-deficient strain of $E$. coli $\mathrm{B}$ when it was irradiated in the absence of oxygen than in its presence, the sensitivity ratios being, respectively, 3.03 and $2 \cdot 07$.

It is difficult to estimate the increase in sensitivity of the Escherichia coli B 5-BU bacteria to u.v. radiation because of the variation in sensitivity of the thymine bacteria. However, when measured at the $10 \%$ survival value, the sensitization factor is at least $\mathbf{2 \cdot 3}$. Therefore, the sensitization caused by $\mathbf{5 - B U}$ is most effective after u.v. radiation and least effective after $\gamma$-radiation in the presence of oxygen.

Treatment of Escherichia coli B with chloramphenicol for an interval after exposure to $\gamma$-radiation or u.v. radiation caused an increase to take place in the colonyforming ability of both 5-BU bacteria and thymine bacteria. It was difficult to obtain an exact measure of the effectiveness of chloramphenicol in restoring the irradiated bacteria, but an estimate of the Rescue Index at $10 \%$ survival was made from the data presented in Figs. 7, 10 and 12. These values are presented in Table 3 and can be used to compare the extent of restoration by chloramphenicol of damage caused under the three conditions of irradiation. Two features are apparent. First, restoration was greatest after u.v. radiation and least after $\gamma$-radiation in the presence of oxygen in both 5-BU bacteria and thymine bacteria. Secondly, after $\gamma$ radiation the restoration of 5 -BU bacteria was relatively greater than that of thymine bacteria. Thus the radiation conditions under which most sensitization by 5 -BU occurred were also those after which most restoration with chloramphenicol took place. Therefore it may be that the same type of damage is enhanced by the one agent and restored by the other. Although no direct examination was made of the location of the 5-BU in the $E$. coli B used here it seems clear from observations 
by other workers (Greer, 1960; Kaplan, Smith \& Tomlin, 1962) that radiationsensitization only occurs when 5-BU replaces some of the thymine in the DNA. Thus the location of this lesion can be defined and it seems reasonable to suppose that treatment with chloramphenicol decreases the expression of some of this damage in DNA.

Table 3. The extent of restoration of Escherichia coli в containing thymine (thymine bacteria) or 5-BU (5-BU bacteria) by incubation on a nutrient medium containing chloramphenicol, after different radiation treatments

\begin{tabular}{|c|c|c|c|}
\hline Rescue Index = & \multicolumn{3}{|c|}{$\begin{array}{l}\text { Maximum number of irradiated bacteria } \\
\text { restored by chloramphenicol treatment } \\
\text { Number of irradiated bacteria which } \\
\text { survive without chloramphenicol treatment }\end{array}$} \\
\hline Irradiation & $\begin{array}{c}\text { 5-BU } \\
\text { bacteria }\end{array}$ & $\begin{array}{r}\text { Thymine } \\
\text { bacteria }\end{array}$ & Ratio of $\frac{\text { R. I. (5-B U bacteria) }}{\text { R. I. (thymine bacteria) }}$ \\
\hline$\gamma$-radiation, aerobic & 22 & 7 & $3 \cdot 14$ \\
\hline$\gamma$-radiation, anaerobic & 43 & 20 & $2 \cdot 15$ \\
\hline u.v. radiation & $\mathbf{5 2}$ & 52 & $1 \cdot 00$ \\
\hline
\end{tabular}

The dependence of the extent of sensitization by 5-BU and of the amount of restoration effected by chloramphenicol on the conditions under which Escherichia coli B was irradiated can be explained by a model proposed by Alper $(1962,1963)$. She concluded from a study of the dependence of the magnitude of the oxygen effect on post-irradiation cultural conditions in E. coli B (Alper \& Gillies, 1958; Alper, 1961) that radiation damage in this strain can be divided into at least two classes, either of which can be lethal to the bacteria; these she called type $\mathbf{N}$ and type $\mathbf{O}$. Type $\mathbf{N}$ damage is characterized by being more readily decreased after irradiation by treatment with inhibitors of protein synthesis or by poor growth conditions, for example, The sensitization of the lesion to ionizing radiation by oxygen is small. Type $\mathbf{O}$ damage, on the other hand, is not modified by post-irradiation treatments and has a much larger oxygen enhancement ratio. Whether a bacterium suffers lethal type $\mathbf{O}$ or type $\mathbf{N}$ damage will depend on the conditions at the time of irradiation, and also on the nature of the post-irradiation growth conditions. Thus a larger proportion of $\boldsymbol{E}$. coli B will be inactivated as a result of type-O lesions when they are exposed to ionizing radiation in the presence of oxygen than when irradiated in its absence. Also the proportion of bacteria which suffer lethal type $\mathbf{N}$ damage will be decreased when they are placed in conditions after irradiation which decrease the expression of type- $\mathrm{N}$ lesions, In u.v. irradiated bacteria, the damage will be largely type $\mathbf{N}$ in nature, because no oxygen effect is associated with exposure to u.v. radiation and therefore no type-O damage will occur. Since u.v. radiation is absorbed principally in the nucleic acids, Alper suggested that type- $\mathrm{N}$ damage is located in the nucleic acids. Therefore the presence of 5-BU in DNA would be expected to increase the expression of damage caused by type- $\mathbf{N}$ lesions. It would follow that greater sensitization by 5 -BU would occur under conditions in which more type $\mathbf{N}$ damage is likely to occur. This is borne out by the findings that sensitization of $E$. coli в by 5-BU was greatest with u.v. radiation, less with anoxic $\gamma$ - 
radiation when some of the lethal damage is also due to type-O lesions and least with aerobic $\gamma$-radiation when the proportion of type-O lesions is further increased. If treatment with chloramphenicol effects restoration by causing a decrease in the amount of type- $\mathbf{N}$ damage but not of type $\mathbf{O}$ damage which is expressed, then the effectiveness of the chloramphenicol will be greatest after conditions of radiation in which the proportion of lethal type-N damage is largest, i.e. after u.v. irradiation of 5-BU or thymine bacteria. Less restoration of 5-BU bacteria will be observed after anoxic $\gamma$ radiation than after $u$.v. radiation because a proportion of the lethal damage will be caused by type-O lesions against which chloramphenicol is ineffective, but the extent of 'rescue' will be more than that seen in anoxically $\gamma$-irradiated thymine bacteria in which the fraction of lethal type- $\mathrm{N}$ damage is further decreased. In the same way it can be argued that resoration of aerobically $\gamma$-irradiated bacteria will be even less, but that the 5-BU bacteria will be restored to a greater extent than the thymine bacteria. The data shown in Table 3 bear out these predictions.

It is interesting that the u.v. irradiated 5-BU bacteria can be restored to such a marked degree by treatment with chloramphenicol, because reports by other authors have indicated that photo-reactivation of bacteria or bacteriophage which contain 5-BU or 5-bromodeoxyuridine (5-BUDR) is prevented or markedly decreased (Greer, 1960; Lorkiewitz \& Szybalski, 1960; Stahl et al. 1961). Host cell reactivation of phage T1 which contained 5-BUDR is also much diminished (Sauerbier, 1961; Howard-Flanders, Boyce \& Theriot, 1962). Shugar (1965) suggested that reactivation of 5-BU-containing micro-organisms might be relatively ineffective because repair enzymes (Setlow \& Carrier, 1964; Boyce \& Howard-Flanders, 1964) which appear to mediate the removal of thymine dimers induced in the DNA by u.v. radiation probably are unable to split the dimer formed between thymine and 5-BU. The present data suggest that restoration by chloramphenicol may not involve repair enzymes.

So far no completely satisfactory explanation has been put forward to account for the radiation sensitization by halogenated pyrimidines incorporated in cells. It has been suggested that the presence of 5-BU in DNA may prevent endogenous recovery processes from operating after irradiation, thereby producing an apparent sensitizing effect. Evidence for this in bacteria and bacteriophages was reviewed by Howard-Flanders (1961); recent work by Lett, Parkins, Alexander \& Ormerod (1964) led these authors to conclude that 5-BUDR may interfere with recovery processes in mammalian cells. The present findings indicate that at least in Escherichia coli $\mathrm{B}$, although spontaneous recovery mechanisms may be blocked by 5-BU, nevertheless restoration can be induced to take place under conditions which temporarily inhibit protein synthesis after irradiation.

I thank Miss Tikvah Alper and Professor D. R. Newth for their advice and help during the preparation of this paper. I am most grateful to Dr M. Pike for his advice on the statistical handling of some of the data and to Miss Barbara Porter and Mr M. Khan for skilful and enthusiastic technical assistance. 


\section{REFERENCES}

AlPER, T. (1955). Bacteriophage as indicator in radiation chemistry. Radiat. Res. 2, 119. AtPER, T. (1961). Variability in the oxygen effect observed with microorganisms. II. Escherichia coli в. Int. J. Radiat. Biol. 3, 369.

ALPER, T. (1962). Evidence for two resolvable sites of action of radiation on microorganisms. Abh. dtsch. Akad. Wiss, Berl., Klasse für Medizin, no. 1, p. 153.

Alper, T. (1963). Lethal mutations and cell death. Phys. Med. Biol. 8, 365.

Alper, T. \& Gillies, N. E. (1958). Restoration of Escherichia coli strain B after irradiation; its dependence on suboptimal growth conditions. J. gen. Microbiol. 18, 461.

Alper, T. \& Giluies, N. E. (1960). The relationship between growth and survival after irradiation of Escherichia coli strain B and two resistant mutants. J. gen. Microbiol. 22, 113.

Alper, T. \& Moore, J. L. (1964). The interaction of some modifying treatments with the sensitizing action of 5-bromouracil in bacteria. (Abstract) Brit. J. Radiol. 37, 803.

Boyce, R. P. \& Howard-Flanders, P. (1964). Release of u.v. light induced thymine dimers from DNA in Escherichia coli $\mathrm{x} 12$. Proc. natn. Acad. Sci., U.S.A. 51, 293.

Doudney, C. O. \& HaAs, F. L. (1958). Modification of ultraviolet-induced mutation frequency and survival of bacteria by post-irradiation treatment. Proc. natn. Acad. Sci., U.S.A. 44, 390.

Forage, A. J. \& Gillies, N. E. (1964). Restoration of Escherichia coli strain B after $\gamma$-irradiation. J. gen. Microbiol. 37, 33.

GILLIES, N. E. (1961). The use of auxotrophic mutants to study restoration in Escherichia coli в after ultraviolet irradiation. Int. J. Radiat. Biol. 3, 379.

Gillies, N. E. \& Alper, T. (1959). Reduction in the lethal effects of radiation on Escherichia coli в by treatment with chloramphenicol. Nature, Lond. 183, 237.

GREER, S. (1960). Studies on ultra-violet irradiation of Escherichia coli containing 5-bromouracil in its DNA. J. gen. Microbiol. 22, 618.

Howard-Flanders, P. (1961). Factors affecting radiation injury to DNA in bacteria and bacteriophage systems. In Fundamental Aspects of Radiosensitivity. Brookhaven Symp. Biol. no. 14, p. 18.

Howard-Flanders, P., Boyce, R. P. \& Theriot, L. (1962). Mechanism of sensitization to ultra-violet light of $\mathrm{T} 1$ bacteriophage by the incorporation of 5 -bromodeoxyuridine or by pre-irradiation of the host cell, Nature, Lond. 195, 51 .

Kaplan, H. S., Smith, K. C. \& Tomlin, P. A. (1962). Effect of halogenated pyrimidines on radiosensitivity of $E$. coli. Radiat. Res. 16, 98.

Kaplan, H. S., Zavarine, R. \& Earle, J. (1962). Interaction of the oxygen effect and radiosensitization produced by base analogues incorporated into deoxyribonucleic acid. Nature, Lond. 194, 662.

LEDERBERG, J. (1950). Isolation and characterisation of biochemical mutants of bacteria. Meth. med. Res. 3, 5.

Lett, J. T., Parkins, G., Alexander, P. \& Ormerod, M. G. (1964). Mechanisms of sensitization to $\mathrm{X}$-rays of mammalian cells by 5 -bromodeoxyuridine. Nature, Lond. 203, 593.

LoRkIEwITZ, Z. \& SzyBaLsKI, W. (1960). Genetic effects of halogenated thymidine analogs incorporated during thymidylate synthetase inhibition. Biochem. biophys. Res. Comm. 2 , 413.

Mrluer, N. \& Wilkinson, J. (1952). Actinometry of ionizing radiations. Discuss. Faraday Soc. $12,50$.

Moore, P. G. \& Edwards, D. E. (1965). Standard Statistical Calculations. London: Pitman.

SAUErbier, W. (1961). The influence of 5-bromodeoxyuridine substitution on uv sensitivity, host-cell reactivation, and photoreactivation in T1 and P22H5. Virology 15, 465.

Setrow, R. B. \& Carrier, W. L. (1964). The disappearance of thymine dimers from DNA: an error-correcting mechanism. Proc. natn. Acad. Sci. U.S.A. 51, 226.

Shugar, D. (1965). Quoted in Recent Progress in Photobiology, p. 86. Oxford: Blackwell. 
Stahl, F. W., Crasemann, J. M., Okun, L., Fox, E. \& Laird, C. (1961). Radiationsensitivity of bacteriophage containing 5-bromodeoxyuridine. Virology 13, 98.

Witkin, E. M. (1956). Time, temperature and protein synthesis; a study of ultravioletinduced mutation in bacteria. Cold Spr. Harb. Symp. quant. Biol. 21, 123.

Witkin, E. M. \& TreiL, E. C. (1960). The effect of post-irradiation treatment with chloramphenicol on various UV-induced mutations in E. coli. Proc. natn. Acad. Sci. U.S.A. 46, 226. 